\title{
1 \\ Brokering in colonial exploration: Biographies, geographies and histories
}

\author{
Tiffany Shellam, Maria Nugent, \\ Shino Konishi and Allison Cadzow
}

The history of exploration has often been thought of as a heroic drama in which the explorer is the principal, sometimes exclusive, protagonist and narrator. This edited volume - along with a companion volume Indigenous Intermediaries: New Perspectives on Exploration Archives - treats exploration as a collective effort and experience involving a variety of people from across social strata and cultures coming together, sometimes for a sustained time, at others only briefly, in various kinds of relationships and interactions. It engages with the recent resurgence of interest in the history of exploration by focusing primarily on the intermediaries - the guides, translators, hosts, labourers and myriad other 'locals' - who became involved in expeditions and assisted and facilitated European explorers who ventured out into the world from the eighteenth through to the twentieth centuries. ${ }^{1}$

\footnotetext{
1 See, for instance, Driver and Jones 2009; Kennedy 2013; Metcalf 2005; Schaffer et al. 2009; Thomas 2015. Earlier works include Reynolds 1990; Baker 1993; Baker 1998.
} 
While the myth of the solitary intrepid explorer has long been questioned, the notion of exploration still suggests the discovery of a wilderness. This collection unsettles this persistent mythology by examining the extent to which the territories and regions that attracted explorers and travellers, who were often themselves impelled by the romance of 'first discovery' or the idea of untouched wilderness, were in fact peopled landscapes, long inhabited by Indigenous people as well as by the vanguards of empire-fortune-hunters such as beachcombers, sealers, labour-recruiters and miners, as well as missionaries and patrol officers, among others. In some Pacific contexts, local peoples were used to the arrival of strangers and traders, and extended their hospitality to itinerant Europeans, or incorporated them into their taio (friendship) ceremonies. ${ }^{2}$ This was also true of many northern Aboriginal coastal groups who had established transactional relationships with Macassan trepang fishermen prior to exploration encounters with Europeans. ${ }^{3}$

In recent years, there has been renewed interest in the ways in which European explorers, travellers and other sojourners depended fundamentally for support, food, shelter, protection, information, guidance, emotional solace and other resources on local Indigenous people - both those who joined exploration parties and those who were encountered in the course of expeditions. ${ }^{4}$

The scholarship of Henry Reynolds and other scholars in Australia and overseas such as Don Baker, Tim Flannery, Felix Driver and Lowri Jones, and D. Graham Burnett, to name just a few, has been an important step in recognising and recuperating the contributions that Indigenous guides made to the history of exploration, and exploring the agency that they had in terms of the expedition's goals. In With the White People (1990) Henry Reynolds dedicates a chapter to those valiant heroes', the Indigenous advisers who assisted European explorers in 'conquering the [Australian] interior', pointing out that 'their role has rarely been fully appreciated in the innumerable works which have celebrated the achievements of the explorers' ${ }^{5}$ In response to this lack of recognition, Reynolds charted the contributions made by numerous Aboriginal guides to the colonial enterprise of exploration: providing

\footnotetext{
See Smith 2010; Salmond 2003; Matsuda 2012; and Connelly's chapter in this book. See Macknight 2011; Mitchell 1995; Konishi and Nugent 2013: 51-54.

See, for example, Burnett 2002; Driver and Jones 2009; Roller 2010; Kennedy 2013.

Reynolds 1990.
} 
local knowledge and bushcraft as they travelled through country, acting as ambassadors and envoys to the Indigenous inhabitants of new territories entered, and serving as 'private assistants' not only to explorers, but also to colonists and travellers 'venturing into the bush'. Like Reynolds' earlier works, this was an important historiographic intervention, drawing attention to the Indigenous side of the history of Australian exploration. Yet in many respects Reynolds' recasting of Aboriginal guides as 'black pioneers', did little to unsettle the colonial underpinnings of exploration.

However, an understanding of Indigenous perspectives and motives for participating in expeditions is harder to elucidate. Interest in the social subtleties, labour relations and economies of expeditions has contributed to fresh analysis which is alert to the shifting and contingent power relations that emerged within exploration parties. This adds to a more sustained interest over the last two or three decades in the nature of cross-cultural relations that emerged during interactions between explorers and Indigenous people. ${ }^{6}$ Indeed, as a number of historians have noted, the challenge for leaders of expeditions, whether on sea or over land, was not only to navigate new terrain but also to manage the interpersonal interactions that were part of the grind - and pleasure - of exploration and travel. While more attention has been given to this aspect of the social history of exploration, it has not generally included the ways in which Indigenous participants in imperial exploration also manoeuvred within the social and interpersonal contexts of exploration.

Dane Kennedy argues in The Last Blank Spaces: Exploring Africa and Australia that the power dynamics inherent in exploration were complex and uneven, and many Indigenous guides had little choice in joining expeditions. He describes such brokers as 'marginal men' who had been 'ripped from their own communities and forced by the circumstances of their estrangement to forge a new niche for themselves at the intersection of cultures' ${ }^{\prime}{ }^{7}$ Kennedy also highlights the 'remarkable ability' of Aboriginal brokers Charley Fisher and Harry Brown 'to retain a real measure of autonomy, dignity, and even authority in their dealings with [Ludwig] Leichhardt' during his

6 Greenblatt 1991; Pratt 1992; Thomas 2004; Salmond 2003; Jolly et al. 2009; Shellam 2009; Nugent 2009; Smith 2010; Konishi 2012; West-Sooby 2013; Douglas 2014.

7 Kennedy 2013: 166. 
expedition. ${ }^{8}$ While this is an important reminder of the dynamics at play in some expeditions, not all Indigenous intermediaries involved in exploration were able to assert their influence or have their authority recognised, as many of the chapters in this collection reveal.

Recent international scholarship on go-betweens in colonial contexts highlights the 'complex and shifting loyalties' at play. In Go-Betweens and the Colonization of Brazil: 1500-1600, Alida Metcalf explores the lasting effect brokers had, from translating during first encounters to becoming prominent figures during possession and colonial settlement. She argues that 'go-betweens clearly took centre stage, for they were the means of communication in the middle grounds of encounters'. ${ }^{9}$ Drawing on the now iconic Nahua go-between Malintzin, or Doña Marina, who mediated for Hernán Cortés, Metcalf highlights the capacity for brokers to open up spaces for the colonisers and themselves, stressing the triangular dynamic that their presence created. ${ }^{10}$ In this triangular relationship, Metcalf argues, brokers 'occupied an intermediate space between worlds where a boundary could become a borderland'. ${ }^{11}$ Australian scholar David Turnbull has similarly illuminated the ways in which brokers opened up boundaries and created borderlands, suggesting it was the cultural dexterity or mobility of these go-betweens that created new knowledge spaces and gave them the ability to draw new boundaries. Turnbull reflects on the power and changing loyalties of brokers who can 'both dissolve and create boundaries in the process of linking people, practices and places in networks'. ${ }^{12}$ Metcalf also stresses the mobility of brokers, suggesting that they were not neutral figures, but people whose fluid alliances could influence the power dynamics at play in the relations between Indigenous and European worlds. Focusing on the third space that a broker's presence enabled, she argues that they created a further dimension of power and could 'exploit their positions for their own benefit because he or she is indifferent to the outcome' ${ }^{13}$

8 Kennedy 2013: 162.

9 Metcalf 2005: 8. See also Yannakakis 2008.

10 Metcalf 2005: 8. See also Godayol 2012.

11 Metcalf 2005: 8.

12 Turnbull 2009: 396.

13 Metcalf 2005: 3. 
The authors in this collection tease out the ways in which Indigenous people or individuals, whether attached to expeditions or encountering them on their own estates, made their own 'strategic' and adroit uses of expedition parties or of particular members of them. Some authors glean and speculate about what it might have meant for some Indigenous people - men and women, young and old, single and attached - to build relationships with expedition leaders and expedition members. Both Clint Bracknell and Shino Konishi, for instance, highlight the way in which expeditions provided opportunities for Indigenous individuals to increase their own political sway within their polities. Allison Cadzow analyses the complexities that arose when the intermediaries were Aboriginal women: they were assumed to pose less of a threat to Aboriginal groups wary of strangers, but at the same time viewed with suspicion by the explorers as duplicitous Eves, who might collude with 'the natives'. These Indigenous travellers, who were experiencing and embracing new forms of social as well as geographical mobility, ${ }^{14}$ had to be - or to become - adept at handling fraught and unpredictable social situations that were riven with competing interests, difficult personalities, contradictory desires, impossible expectations and unfamiliar values, all of which could be intensified and magnified by the cheek-by-jowl living arrangements that exploring inevitably involved. Relationships between explorers and Indigenous guides were never merely contractual or transactional in a purely economic sense. Typically they functioned according to unstated expectations on all sides around patronage and favour, honour and trust, faithfulness and obedience, obligation and incentive. ${ }^{15}$ Teasing out what might have been the stakes involved for Indigenous intermediaries in exploration parties in terms of forming alliances, earning debts and obligations, leveraging resources and status, currying favour and gaining advantage not only with Europeans but also their own kin, allies and enemies, reflects and generates a particular emphasis on Indigenous people and perspectives within histories of exploration that provides a necessary and long called for correction to the broader historiography of exploration. 
Australia and its neighbour New Guinea provide the geographical scope of the collection. In addition to the long history of Indigenous cultural exchange between Indigenous Australians and Papuans conducted via the Torres Strait, Australia and New Guinea have overlapping histories of exploration, stemming from the Dutch VOC whose explorers in the seventeenth century charted the coastlines of both, and continuing into the nineteenth century when explorers such as Louis Freycinet landed at sites in both countries (see Nicole Starbuck's chapter). They also have entwined histories of colonisation, with key colonial figures having established their careers in both colonies. ${ }^{16}$ For instance, William MacGregor, the subject of Andrew Connelly's chapter, was a colonial administrator in British New Guinea before becoming the Governor of Queensland. Such entangled histories of exploration and colonisation illustrate how cross-cultural interactions and (mis)understandings were not only shaped by the immediate actions of European and Indigenous individuals involved. They were also the legacy of earlier interactions with other Indigenous peoples from different parts of the empire. ${ }^{17}$

The chapters on Australian exploration in the collection include Bracknell's study of Bobby Roberts, a Noongar intermediary from south-western Western Australia, and Cadzow's account of Aboriginal women's role in expeditions in Tasmania, Victoria and New South Wales. Konishi and Mark Dunn both examine exploration in New South Wales. Konishi offers a study of two intermediaries: Bennelong, who was an infamous cultural broker in the early years of the Port Jackson colony, and the lesser known and seemingly mercurial guide Gogy, who was involved in Barrallier's thwarted attempt to cross the Blue Mountains. Dunn's is a survey of the diverse roles of Aboriginal guides in a number of excursions in the Hunter region, which included tracking runaway convicts, carrying messages, and guiding expeditions. The chapters on New Guinea include Chris Ballard's evocation of five actual and fictional expeditions into the interior; Starbuck's reading of the influence of interactions with Papuan intermediaries at Waigeo and Dorey Bay in 1819 and 1827 on French 'racial' thought; and Dario Di Rosa's examination of Francis Blackwood's 1845 exploration of the Gulf of Papua. Connolly's chapter

16 For a broader study of such imperial mobility and networks, see Lambert and Lester 2006.

17 For more on imperial mobility, see Lester 2005; Lambert and Lester 2006; Ballantyne and Burton 2009; Carey and Lydon 2014. 
is a study of colonial administrator William MacGregor's 'discovery' of the Trobriand Islands (now part of the Milne Bay Province in Papua New Guinea), and the islanders he was ostensibly to superintend.

Common to many of the chapters is attention to the specificities of locality. This has some advantages, not least of which is that they can provide a level of local-based knowledge that provides the bedrock on which to build nuanced insights into and speculations about the often opaque meanings of interactions, episodes and shifting emotions and moods. Some of that knowledge has been gained through intensive fieldwork, revealing, as it does in di Rosa's chapter, the depth in knowing a historical archive, a landscape and local community intimately. Other authors are able to draw upon knowledge that comes with personal and familial connections, such as Bracknell's to the Wirloman Noongar community, and in which one's own relatives are a source and guide within the analysis.

It is not only local knowledge that is brought to the analysis. Some authors also productively ask questions of what the 'local' means, or what it means to be 'local'. These lead also to consideration of ideas of space - and to questions about incommensurate or conflicting ideas about the meanings and significance of space, place or 'country', as well as the meanings and histories of particular locations, sites or 'routes'. For example, Dunn prioritises the political space of Aboriginal country in his chapter on Aboriginal guides in the Hunter region, showing how Aboriginal social spaces frequently dictated explorers' routes through country. By both exploring cross-cultural interactions in particular locations, as well as conceptualising how particular places or conceptualisations of space influenced the nature of such interactions, the collection extends in empirically rich ways some of the earlier 'inroads' into exploration history and writing made by scholars such as Paul Carter, Ross Gibson, Mary-Louise Pratt and Simon Ryan a decade or two ago. ${ }^{18}$ Other contributors to this volume bring frameworks of 'race' and 'gender' to bear on the narratives of exploration. Cadzow's chapter discusses the absence of women in the historiography of exploration arguing that Aboriginal women were actually present and active agents in exploration in particular, political ways. Starbuck's chapter on French-West Papuan 
encounters reads French expedition texts to reveal how discourses on 'race' within these encounters also suggest the presence of strong Indigenous agency.

A focus on the local in this volume is matched by an emphasis on the biographical. Biographical-influenced approaches, where analysis is focused closely on an individual life or a group of lives, is a methodology and narrative strategy used by several of the authors in this collection, to powerful effect. This reflects a growing appreciation that 'the detailed analysis of individual or collective lives offers one of the best ways to explore' diverse experiences as well as wider histories of race, gender, and class. ${ }^{19}$ More recently, Jane Carey and Jane Lydon have also recognised the important value of biographical approaches, asserting that they allow us 'to vividly demonstrate the experience and impact of individuals within global trajectories of movement and exchange'. They add that '[l]ife stories link the transnational and the personal by incorporating both the specificities and intimacies of individual lives with macro circulations of trade, knowledge and state power'. ${ }^{20}$

Still, some historians take a disdainful view of biography, seeing it as a 'faintly suspect' historical method. ${ }^{21}$ Certainly, there are reasons to be wary. Biography can be too individualising at the expense of understanding broader processes, contexts and group associations. Felix Driver has argued there is the risk of substituting, merely replacing a heroic myth of an individual (the explorer) with another (the broker or intermediary). ${ }^{22}$ Similarly, David Philip Miller has warned against too great a focus on intermediaries, for it could lead 'us to neglect the larger forces within which they operated'. He states that it is 'easy in our fascination' with these colourful, puzzling characters to overstate their agency. ${ }^{23}$ Miller is right to urge us to find a balance between the mythic explorer-hero narrative from which intermediaries were excluded, and the 'add guides and stir' approach.

\footnotetext{
19 Caine 2010: 3.

20 Carey and Lydon 2014: 10-11.

21 Evans and Reynolds 2012: 1.

22 Driver 2013: 8.

23 Miller 2011: 613.
} 
However, these concerns can be mitigated by situating individual studies carefully, in a manner akin to microhistory and ethnohistory, where the examination of a broker's life can serve to tease out a broader picture, while respecting its particularities, as in Bracknell's reflective discussion of the life of Bobby Roberts. This is an approach that other authors in the volume also take. In addition to discussing the work brokers do within an expedition, the authors also study brokers by tracking their lives beyond the expedition and speculating about their possible motivations for participating in exploration. A focus on their larger lives provides a powerful counterpoint to historical representations that cast them as anonymous assistants: the 'native boy' or the 'blackfellow'. The analysis needs to take account of Indigenous brokers' views, agendas and actions too. Comparisons can be drawn between key figures to ascertain common tactics, rather than presenting an account of an artificially isolated individual. This is evident in Konishi's chapter where Bennelong and Gogy are compared, which enables new ways of reading Gogy's actions. What results is a more subtly rendered picture of the dynamic nature of expedition relationships. These various approaches reinforce just how productive a contextualised biographical approach can be. It creates a space for a deeper investigation of brokers' lives and actions, which explorer accounts too often discuss fleetingly, gloss over, or give the impression that the broker lived and breathed for the moment of the expedition and nothing more.

The chapters in this collection remind us of the pivotal and enduring role that exploration played in European imperialism and colonisation, as the European newcomers grappled with understanding and negotiating the diverse environments and landscapes of Australia and New Guinea in order to claim it as their own. Despite their obfuscating representational practices and the myth that these new lands were a tabula rasa - a blank slate to be inscribed by European territorial claims - European explorers were keenly aware that they traversed Indigenous lands, made up of distinct territories, occupied by different peoples and clans. This was one of the many reasons why the Europeans sought out Indigenous brokers who could mediate their encounters with different groups, and negotiate their needs and desires, be it basic wants such as water, food, and peaceful passage, or to facilitate their colonial ambitions and cement imperial reputations through acquiring esteemed geographic knowledge, or to attempt to 
secure administrative control over the 'natives', or just to establish nascent communication networks over vast areas. This volume adds to exploration scholarship more broadly by uncovering new stories of Indigenous brokers as well as offering new readings of their experiences. But it is not only to histories of exploration that this volume contributes. The work of brokering was necessitated by and embedded in colonial structures, relations and histories. And so by studying the ways in which these men and women tested, pushed and remade boundaries, shared or withheld their knowledge, forged and managed relations with explorers and their own countrymen and women, new insights and perspectives are also offered on colonial processes. We hope this book follows their lead, brokering further discussions, debates, and understandings of the complexities, cross cultural impacts and historical significance of brokering and boundary crossing.

\section{References}

Baker, Don 1993, 'John Piper: Conqueror of the Interior', Aboriginal History 17(1): 17-37.

1998, 'Exploring with Aborigines: Thomas Mitchell and his Aboriginal guides', Aboriginal History 22: 36-50.

Ballantyne, Tony and Antoinette M. Burton (eds) 2009, Moving Subjects: Gender, Mobility, and Intimacy in an Age of Global Empire, University of Illinois Press, Urbana.

Burnett, D. Graham 2002, "'It is impossible to make a step without the Indians": Nineteenth-century geographical exploration and the Amerindians of British Guiana', Ethnohistory 49(1): 3-40.

Caine, Barbara 2010, Biography and History, Palgrave Macmillan, Houndmills, Basingstoke.

Carey, Jane and Jane Lydon (eds) 2014, Indigenous Networks: Mobility, Connections and Exchange, Routledge, London.

Carter, Paul 1987, The Road to Botany Bay: An Essay in Spatial History, Faber and Faber, London. 
Douglas, Bronwen 2014, Science, Voyages, and Encounters in Oceania, 1511-1850, Palgrave Macmillan, Houndmills, Basingstoke.

Driver, Felix 2013, 'Hidden Histories made visible? Reflections on a geographical exhibition', Transactions of the Institute of British Geographers 38: 420-435.

Driver, Felix and Lowri Jones 2009, Hidden Histories of Exploration: Researching Geographical Collections, Royal Holloway, University of London, and Royal Geographical Society (with IBG), London.

Evans, Tanya and Robert Reynolds 2012, 'Introduction to this special issue on biography and life-writing', Australian Historical Studies 43(1): $1-8$.

Gibson, Ross 2012, 26 Views of the Starburst World: William Dawes at Sydney Cove 1788-91, UWA Publishing, Crawley.

Godayol, Pilar 2012, 'Malintzin/La Malinche/Doña Marina: re-reading the myth of the treacherous translator', Journal of Iberian and Latin American Studies 18(1): 61-76.

Greenblatt, Stephen 1991, Marvellous Possessions: The Wonder of the New World, Oxford University Press, Oxford.

Jolly, Margaret, Serge Tcherkézoff and Darrel Tryon (eds) 2009, Oceanic Encounters: Exchange, Desire, Violence, ANU E Press, Canberra.

Kennedy, Dane 2013, The Last Blank Spaces: Exploring Africa and Australia, Harvard University Press, Cambridge, MA.

Konishi, Shino 2012, The Aboriginal Male in the Enlightenment World, Pickering \& Chatto, London.

Konishi, Shino and Maria Nugent 2013, 'Newcomers, c. 1600-1800', in The Cambridge History of Australia: Volume 1: Indigenous and Colonial Australia, Alison Bashford and Stuart Macintyre (eds), Cambridge University Press, Melbourne, 43-67.

Lambert, David and Alan Lester (eds) 2006, Colonial Lives Across the British Empire: Imperial Careering in the Long Nineteenth Century, Cambridge University Press, Cambridge. 
Lester, Alan 2005, Imperial Networks: Creating Identities in NineteenthCentury South Africa and Britain, Routledge, New York.

Macknight, Campbell 2011, 'The view from Marege': Australian knowledge of Makassar and the impact of the trepan industry across two centuries', Aboriginal History 35: 121-144.

Matsuda, Matt K. 2012, Pacific Worlds: A History of Seas, Peoples, and Cultures, Cambridge University Press, Cambridge.

Metcalf, Alida C. 2005, Go-Betweens and the Colonization of Brazil: 1500-1600, University of Texas Press, Austin.

Miller, David Philip 2011, 'History from between', Technology and Culture 52(3): 610-613.

Mitchell, Scott 1995, ‘Foreign Contact and Indigenous Exchange Networks on the Cobourg Peninsula, North-Western Arnhem Land', Australian Aboriginal Studies 2: 44-48.

Moore, Clive 2003, New Guinea: Crossing Boundaries and History, University of Hawai'i Press, Honolulu.

Nugent, Maria 2009, Captain Cook Was Here, Cambridge University Press, Melbourne.

Pratt, Mary Louise 1992, Imperial Eyes: Travel Writing and Transculturation, Routledge, London.

Reynolds, Henry 1990, With the White People: The Crucial Role of Aborigines in the Exploration and Development of Australia, Penguin, Ringwood, Vic.

Roller, Heather F. 2010, 'Colonial collecting expeditions and the pursuit of opportunities in the Amazonian Seratao c. 1750-1800', The Americas 66(4) (April): 435-467.

Russell, Lynette 2001, Colonial Frontiers: Indigenous-European Encounters in Settler Societies. Manchester University Press, Manchester.

Russell, Penelope 2010, Savage or Civilised?: Manners in Colonial Australia, UNSW Press, Sydney. 
Ryan, Simon 1996, The Cartographic Eye: How Explorers Saw Australia, Cambridge University Press, Cambridge.

Salmond, Anne 2003, The Trial of The Cannibal Dog: Captain Cook in the South Seas, Allen Lane, London.

Schaffer, Simon, Lissa Roberts, Kapil Raj and James Delbourgo (eds) 2009, The Brokered World: Go-Betweens and Global Intelligence, 1770-1820, Science History Publications, Sagamore Beach, MA.

Shellam, Tiffany 2009, Shaking Hands on the Fringe: Negotiating the Aboriginal World at King George's Sound, UWA Publishing, Perth.

Smith, Vanessa 2010, Intimate Strangers: Friendship, Exchange and Pacific Encounters, Cambridge University Press, Cambridge.

Thomas, Martin 2004, The Artificial Horizon: Imagining the Blue Mountains, Melbourne University Press, Melbourne.

(ed.) 2015, Expedition into Empire: Exploratory Journeys and the Making of the Modern World, Routledge, New York.

Turnbull, David 2009, 'Boundary-crossings, cultural encounters and knowledge spaces in early Australia', in The Brokered World: Go-Betweens and Global Intelligence 1770-1820, Simon Schaffer, Lissa Roberts, Kapil Raj and James Delbourgo (eds), Science History Publications, Sagamore Beach, MA, 387-428.

West-Sooby, John (ed.) 2013, Discovery and Empire: the French in the South Seas, University of Adelaide Press, Adelaide.

Yannakakis, Yanna 2008, The Art of Being In-between: Native Intermediaries, Indian Identity and Local Rule in colonial Oaxaca, Duke University Press, Durham. 
This text is taken from Brokers and Boundaries: Colonial Exploration in Indigenous Territory, edited by Tiffany Shellam, Maria Nugent, Shino Konishi and Allison Cadzow, published 2016 by ANU Press, The Australian National University, Canberra, Australia. 